\title{
Conjoined NO-sensitive guanylyl cyclases
}

\author{
Sönke Behrends*, Mareike Busker, Nadine Haase, Tobias Haase, Jan Krähling, Monika Linnenbaum \\ From 5th International Conference on cGMP: Generators, Effectors and Therapeutic Implications \\ Halle, Germany. 24-26 June 2011
}

\section{Background}

NO-sensitive guanylyl cyclases (NO-GC's) that catalyze the reaction of GTP to the second messenger molecule cGMP are heterodimeric enzymes consisting of an $\alpha$ and a $\beta_{1}$ subunit. The two prevalent isoforms in humans $\left(\alpha_{1} / \beta_{1}, \alpha_{2} / \beta_{1}\right)$ are time-tested targets for drugs that release nitric oxide (NO) and new compounds that either sensitize the enzyme for activation by $\mathrm{NO}$ or activate the enzyme independently of NO. Homologous NO-GC subunits consist of an amino-terminal HNOX domain followed by a PAS- and a coiled coil domain and the carboxy-terminal catalytic domain.

\section{Results}

Measurement of FRET between fluorescent proteins tagged to the amino- and carboxy-terminus of the subunits indicated close proximity between the amino-terminal HNOX domains and the carboxy-terminal catalytic domains of the enzyme. On the basis of these results we constructed conjoined NO-GC's by fusion of the $\alpha$ aminoterminus to the $\beta_{1}$ carboxy-terminus leading to a monomeric enzyme complex. Surprisingly but in accordance with the FRET results these conjoined NO-GC's $\left(\beta_{1} \alpha_{1}\right.$, $\beta_{1} \alpha_{2}$ ) showed specific enzyme activity and stimulation by $\mathrm{NO}$ and various modulators of GC activity.

\section{Conclusion}

These obligate enzyme variants faithfully reproduced the pharmacological properties of the heterodimeric enzymes including an isoform specific differential activation of the NO-independent drug cinaciguat. Novel applications of conjoined NO-GC's including adenoviral gene transfer will be discussed.

Published: 1 August 2011

\footnotetext{
* Correspondence: s.behrends@tu-bs.de

Institut für Pharmakologie, Toxikologie und Klinische Pharmazie, TU Braunschweig, Germany
}

doi:10.1186/1471-2210-11-S1-P6

Cite this article as: Behrends et al:: Conjoined NO-sensitive guanylyl

cyclases. BMC Pharmacology 2011 11(Suppl 1):P6.

\author{
Submit your next manuscript to BioMed Central \\ and take full advantage of: \\ - Convenient online submission \\ - Thorough peer review \\ - No space constraints or color figure charges \\ - Immediate publication on acceptance \\ - Inclusion in PubMed, CAS, Scopus and Google Scholar \\ - Research which is freely available for redistribution \\ Submit your manuscript at \\ www.biomedcentral.com/submit
}

\section{Biomed Central}

(c) 2011 Behrends et al; licensee BioMed Central Ltd. This is an open access article distributed under the terms of the Creative Commons Attribution License (http://creativecommons.org/licenses/by/2.0), which permits unrestricted use, distribution, and reproduction in any medium, provided the original work is properly cited. 